\title{
Mineralogy and Texture of the Weathered Products from Silicic Lavas in the Sabga Area, North West Cameroon
}

\author{
Edith Etakah Bate Tibang1 ${ }^{*}$, Gideon Anoma Waji², Elisha Mutum Shemang ${ }^{3}$, \\ Cheo Emmanuel Suh ${ }^{1,2}$
}

\author{
${ }^{1}$ Department of Geology, Mining \& Environmental Science, Faculty of Science, University of Bamenda, Bambili, North West \\ Region, Cameroon \\ ${ }^{2}$ Economic Geology Unit, Department of Geology, University of Buea, Buea, South West Region, Cameroon \\ ${ }^{3}$ Department of Earth and Environmental Sciences, Botswana International University of Science and Technology, Palapye, \\ Botswana \\ Email: *edithbate@yahoo.com
}

How to cite this paper: Tibang, E.E.B., Waji, G.A., Shemang, E.M. and Suh, C.E. (2021) Mineralogy and Texture of the Weathered Products from Silicic Lavas in the Sabga Area, North West Cameroon. International Journal of Geosciences, 12, 605-624. https://doi.org/10.4236/ijg.2021.126034

Received: May 13, 2021

Accepted: June 27, 2021

Published: June 30, 2021

Copyright (c) 2021 by author(s) and Scientific Research Publishing Inc. This work is licensed under the Creative Commons Attribution International License (CC BY 4.0).

http://creativecommons.org/licenses/by/4.0/

\begin{abstract}
Products of weathering usually clay minerals, are commonly characterized through mineralogical, chemical and geochemical analysis, emphasizing their implications in industrial applications, initiation of landslides and their impact on surface water geochemistry. In this study the vertical variations in textural characteristics and clay mineral type within weathered profiles in the Sabga area were investigated. Two exposed weathered profiles were logged from bed rock to topsoil and each horizon was sampled separately. Granulometric analysis on the samples indicated mixtures of clay, silt and sand size particles in all horizons. Smectite and kaolinite were identified by X-ray diffractometry (XRD) and scanning electron microscopy (SEM). The two logs show that the lower horizons display whitish colors with fine laminations, middle horizons are brownish and the upper horizons display dark brown colors. Graphic mean values for both sections gave values that range between $2.02-3.7 \phi$ with an average standard deviation value of $1.9 \phi$, indicating that the grains are poorly sorted sand, silt and clay. SEM micrographs show laths of smectite in the lower horizons, flakes of kaolinite and laths of smectites in the middle horizons while the upper horizons show flakes of kaolinite with microlites of quartz + feldspars. XRD patterns show broad basal reflections for kaolinite at $2 \theta 36.8^{\circ}(3.15 \AA)$, smectite at $2 \theta 33.5^{\circ}$ (3.34 $\AA$ ), both contaminated with quartz at $2 \theta 36.5^{\circ}(3.32 \AA)$ typical for these minerals.
\end{abstract}

\section{Keywords}

Mineralogy, Texture, SEM, Clay 


\section{Introduction}

The weathering of rocks is the most fundamental geomorphic process which modifies the Earth's surface, and it is one of the vital processes in soil mineral cycling. The intensity and products of chemical weathering in tropical regions are controlled generally by climatic factors (e.g., variations in temperature and rainfall), chemistry, mineralogy, texture and structure of parent rocks, drainage, topography and time [1] [2].

Despite being controlled greatly by climatic factors (variations in temperature and rainfall) [1], is afunction of the chemistry, mineralogy, texture of the parent rock, drainage system and topography, structures, vegetation andtime [2]. For instance studies carried out on weathered profiles of basaltic rocks from the French Massif Central indicated the presence of iddingsite from forsterite, iron oxyhydroxide from augite and halloysite from plagioclase feldspars [3]. [4] studied tropical weathering of recent basalts from Cameroon and described the evolution of the weathered product from parent rock through allophone, halloysite, metahalloysite to gibbsite, as a function of climate, drainage and time. On well drained, upper and middle sections of slopes on suitable rocks, kaolinite develops. On the contrary, downslope or in hindered drainage conditions, kaolinite is gradually replaced by illite/smectite [5].

With the dependence of chemical weathering on the parent rock, the products of weathering on silicic and mafic lavas will differ to a greater extend, since their chemical compositions also differ [1]. For instance study carried out on weathered basalts in Eastern Australia revealed that the minerals altered to a mixture of allophanes, iron oxyhydroxides and clay minerals [6]. [7] showed that Quartz, feldspars, micas and opaque minerals that make up the mineral constituents of silicic lavas (rhyolite to dacite) alter to smectite, illite, kaolinite, chlorite and epidote.

The variability of the geological basement of Cameroon and its location has favored the development of thick weathering profiles [8] [9]. These profiles are generally characterized by the presence of clay deposits which are some of the most important industrial materials as millions of tons are utilized in a vast variety of applications including ceramics, oil drilling and the paper industry. $\mathrm{Nu}-$ merous studies have been carried out on these weathered profiles particularly along the Cameroon Volcanic Line (CVL: e.g., [9]-[16]). These studies have explored the products of weathering, usually clay deposits, with focus on characterizing the type of clay minerals, emphasizing their implications in medicinal and industrial applications including ceramics, oil drilling, pharmaceutical and the paper industry. Most of these works focused more on geochemical and mineralogical quantification of homogenized weathered products without laying emphasis on the bed rock type, vertical variations in texture characteristics and clay mineral type within weathered profiles. Other weathering-related studies have examined the weathering on igneous rocks under specific environmental and climatic conditions with the aim of evaluating their implications in landslides 
development [17] [18].

This study aims to show vertical variations in texture, clay mineral type and their morphology within weathered profiles on rhyolitic rocks in the Sabga area located in the North West Region Cameroon. This allows us to have a better understanding of the systematic evolution of clay minerals within weathered profiles developed from silicic volcanic bed rock. As previous studies in the area also focused on clay mineral characterization on homogenous clay deposits developed on trachyte without paying attention to vertical variation of the clay minerals. X-Ray Diffractometry (XRD) analyses and the scanning electron microscopy (SEM) are used to identify the clay minerals and their morphology in the various horizons.

\section{Geologic Setting}

The Sabga region is part of the Bamenda Mountains an extinct volcano of Western Cameroon highland [19] which in terms of volumetric importance is the fourth largest volcanic massif along the Cameroon Volcanic Line (CVL) (Figure 1). The CVL is a near $1700 \mathrm{~km}, \mathrm{SW}-\mathrm{NE}$ trending, African intraplate "fan shaped", alkaline volcano-plutonic rift zone of variable width $(<200 \mathrm{~km})$, with a ca. $66 \mathrm{Ma}$ history of magmatic activity without any systematic internal pattern of age variation [20]-[25]. The CVL structure is a consequence of a series of parallel fissures oriented $\mathrm{N} 30^{\circ} \mathrm{E}$ and some transversal events [26]. The study area lies midway between Mt. Bambouto to the South-west and the Oku Massifs in the North-east, all being volcanoes along the central part of the continental sector of the CVL. It is inferred to be underlain by older Paleoproterozoic and Pan-African metagranitic basements [25] [27] [28] which is covered by sequences of alternating felsic and mafic units [25] [29].

The felsic lavas are more abundant than their mafic counterparts and are comprised dominantly of rhyolitic lava flows, trachytic, dacitic and rhyodacitic flows as well as welded ignimbrites. The mafic units are mainly alkalis basalts, hawaiites and basanites [25]-[32]. The rhyolitic ignimbrites consist of welded and non-welded massive lapilli tuff and lithic breccias [33]. The welded ignimbrites vary in colour ranging from welded grey, welded greyish brown and dark grey units [25]. The felsic lavas are massive, blocky, moderately to deeply weathered, occur as tongue-like lava flows (coulee), and as domes. The lavas vary in colour from light-grey, grey, dark-grey, dark green to black. They are highly localised and comprised of both coherent and autobrecciated facies which occur at the base and top of coherent facies. The coherent facies are characterised by rhyolitic flow banded and non-banded varieties. Hand samples indicate the presence of dark inclusions, millimetric to centimetric flow bands which are rhythmic and either planar or highly contorted forming flow folds. Some bands display an alignment of vesicles whereas others show alignment of alternating dark and light colour variations (Figures 2(a)-(c)).

Microscopically the coherent lava facies are flow banded, porphyritic with 


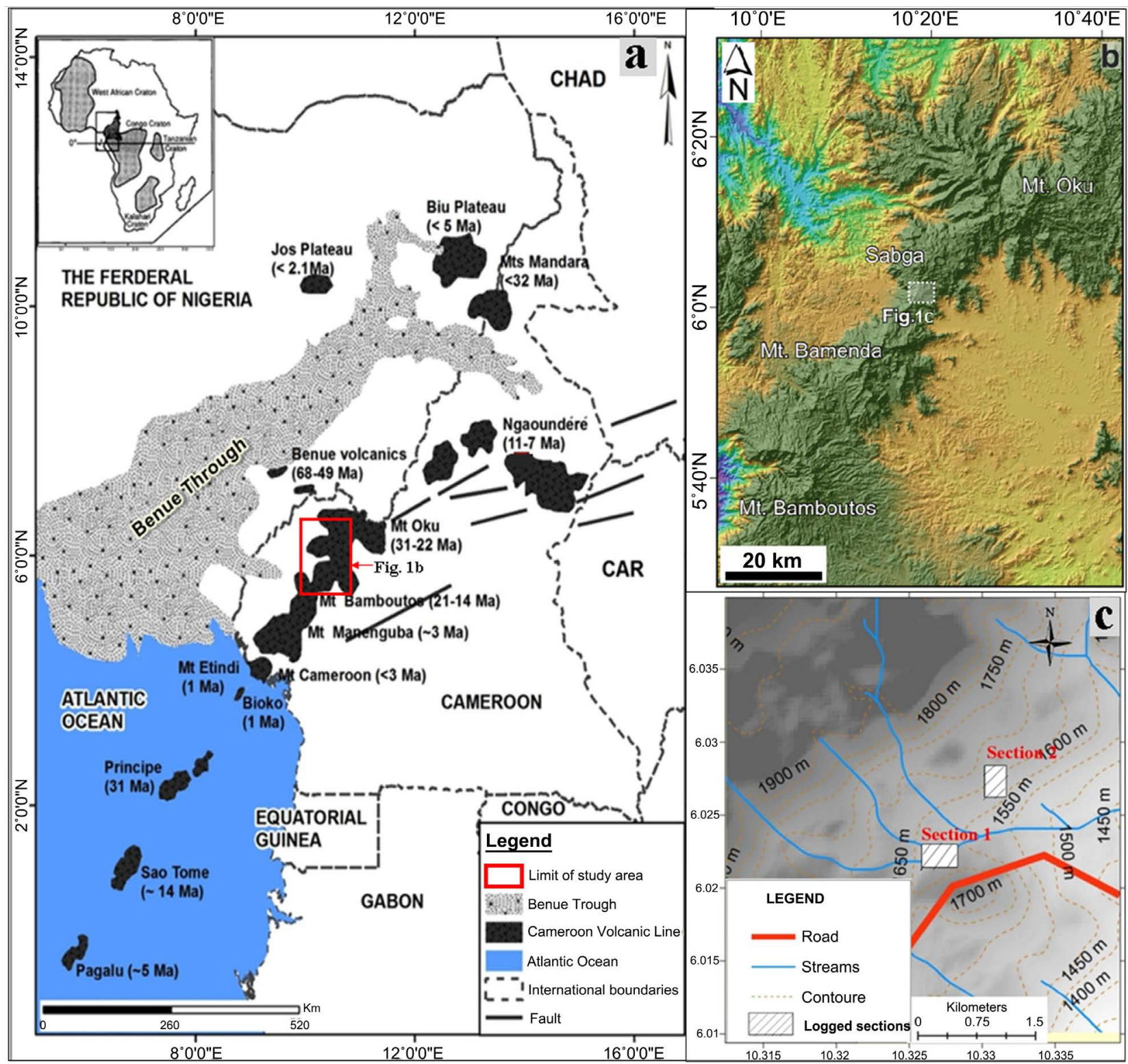

Figure 1. Location of the Sabga area along the Cameroon the Cameroon Volcanic Line (CVL). (a) Location of the study area along the Cameroon Volcanic Line with inset map of Africa. (b) Study area within the Mt. Bamboutos-Mt.Oku zone of the CVL. (c) Drainage, topography and sampled points within the study area. Modified after [25].

phenocrysts modal contents estimated at $8 \%-35 \%$ (Figure 2(c)). They also show a characteristic holocrystalline, to glomeroporphyritic texture (Figure 2(d)) as well as partly weathered feldspar crystal to dirty clayey material. Phenocrysts consist mainly of quartz, sanidine, plagioclase and biotite, and pyroxene with varying sizes up to $8 \mu \mathrm{m}$. Oxides of iron occur as part of the groundmass and also as inclusions within fractured and weathered crystals of biotite and plagioclase. Groundmass textures vary from microscopic flow bands, microspherulitic, microcrystalline, to a glassy groundmass with extensive devitrification (Figure 2(e) and Figure 2(f)). Chlorite and clay minerals occur as alteration products of feldspar and biotite within the groundmass. 

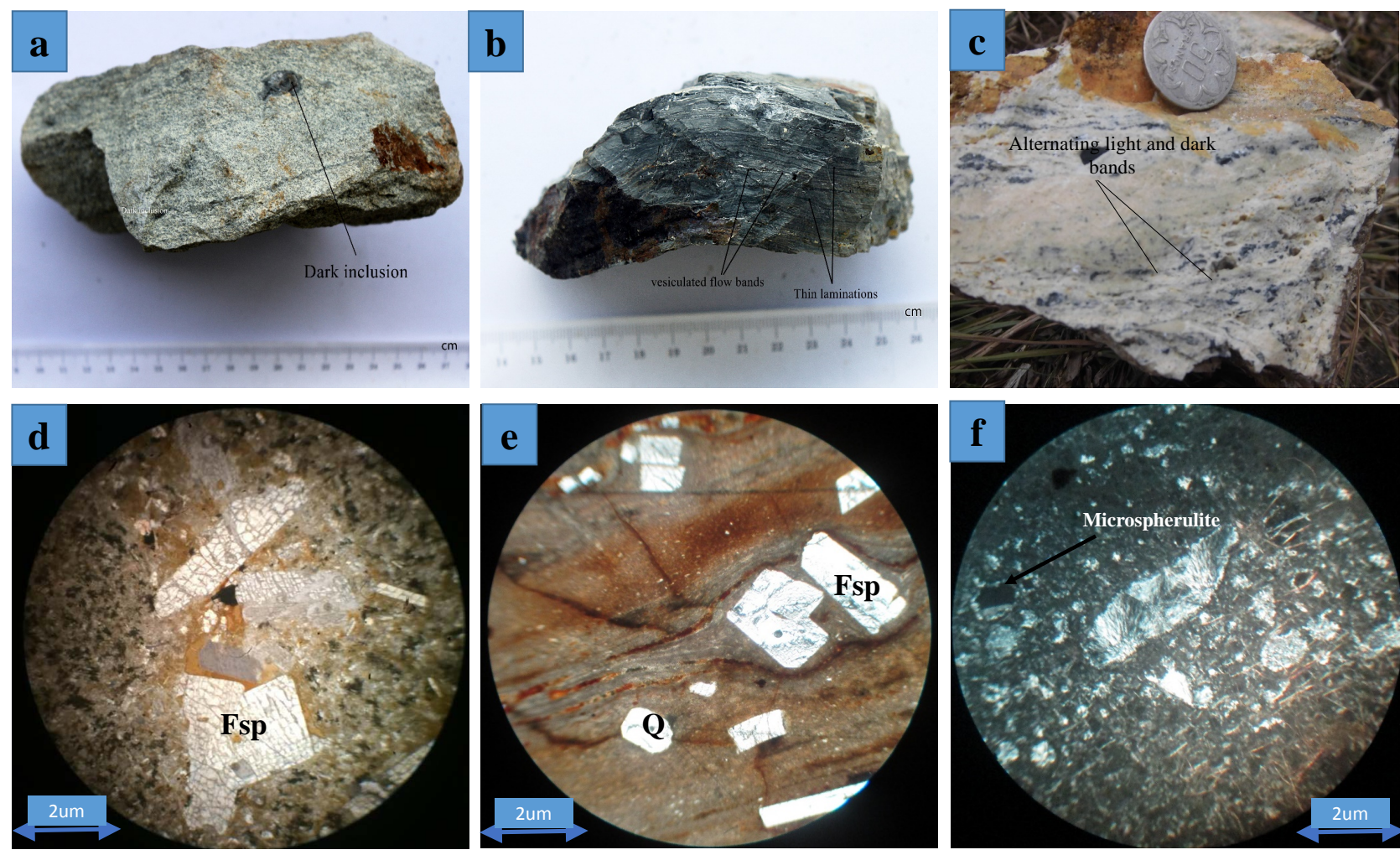

Figure 2. Hand samples and photomicrographs of felsic lava flows the Sabga area; (a) grey dacite showing dark inclusion; (b) dark grey rhyodacite lava showing light and dark bands; (c) light grey rhyolitic lava showing aligned vesicles with glass inclusions; (d) photomicrograph showing a glomeroporphyritic texture; (e) microscopic flow bands swirling around well-formed crystals of sanidine; (f) photomicrographs (after [25]) showing a devitrified, spherulitic groundmass with amygdales. $Q=$ quartz; Fsp = feldspar.

Weathered profiles and rock outcrops are well exposed on slopes and along road cuts. Nonetheless, accessibility to some exposed profiles is limited due to the very steep nature of the cliff faces and rugged nature of the topography. The mapped weathered profiles cover a surface area of $295 \mathrm{~m}^{2}$ (Section 1) and $256 \mathrm{~m}^{2}$ (Section 2). This profile resulted from the weathering of light grey rhyolitic lava flows characterized by alternating light and dark bands (Figure 2(c)). Under the microscope the rhyolite displays a spherulitic and glassy groundmass (Figure 2(f)).

Ages from radiometric dating gives a range from 17.4 - $0 \mathrm{Ma}$ for basaltic rocks and divided the felsic units into two sequences. The younger sequence range in age from 12.5 - 13.5 Ma while the older sequence vary from 27.4 - 18.0 Ma [30] [31]. The Sabga area has Ar-Ar age of 23.0 Ma and Zircon U-Pb ages of $23.0 \pm$ $0.3 \mathrm{Ma}$ and $22.98 \pm 0.28 \mathrm{Ma}$ for two rhyolitic units separated by a basaltic unit [25] [29]. These units form part of the older sequences of the Bamenda Mountain.

\section{Materials and Methods}

Two weathered exposed profiles (S1 and S2: Figure 1(d)) $500 \mathrm{~m}$ apart from silicic volcanic bed rocks were identified. The surface area for each deposit was 
measured and various horizons $(\mathrm{H})$ from bottom to top described with respect to changes in thickness, texture, grain size, grain shape, structures and color. Log diagrams representing each weathered profile were subsequently produced using SedLog 3.0.

Twenty samples collected from the two sections were air dried and crushed separately in cleaned mortar to avoid cross contamination. Weighted $200 \mathrm{~g}$ of each sample from different horizons were sieved through a $4 \mathrm{~mm}-63 \mu \mathrm{m}$ stacked sieve with the help of a sieve shaker for 15 minutes. The grains retained by each size fraction were weighed separately and their values recorded. Their weight percentages and cumulative weight percentages were calculated. Log plots of cumulative percentages finer by weight against grain sizes/phi sizes for each sample were computed in Microsoft excel 2013. The $<63 \mu \mathrm{m}$ were analyzed for XRD patterns and SEM at the Electron Microscopy Unit (EMU) of the University of Botswana, Gaborone. The Samples for SEM analysis were prepared following the methods described by [34] and [35] and analyzed using the Scanning Electron Microscope model XL30 (University of Botswana, EMU). During sample preparation the $<63 \mu \mathrm{m}$ powdered sample was treated by dipping in cross-linked proteins to increase their stability, they were then removed and put in lipids to increase their conductivity and minimize image distortion due to charging. The specimen was then removed and dehydrated by incubation in a series of ethanol solution. To avoid micro ripping of the surface of the samples, the ethanol was replaced by carbon dioxide liquid for 30 minutes. The sample was then mounted on a metal stub using a sticky carbon disc and coated with a conductivity gold metal using a sputter coater. 2D images were generated over a resolution of 4.0 spots with magnifications ranging between $200-10,000 \mathrm{X}$ with a secondary electron detector at a voltage of $20 \mathrm{Kv}$. XRD analysis was performed on the dried < $63 \mu \mathrm{m}$ powder sample using Bruker AXS D8 diffractometer and the pattern recorded over the $1-70^{\circ} 2 \theta$ range, using a scanning step of $0.05^{\circ} 2 \theta$ at a step count of 10 seconds. The analytical conditions are as provided in [36].

\section{Results}

\subsection{Vertical Variations from Top to Buttom}

The detailed logs for S1 and S2 are provided in Figure 3(a) and Figure 3(b). Corresponding field photographs (Figure 4 and Figure 5) are also provided to reveal the details of the color and textural parameters (physical characteristics) of the various horizons that range from saprolite at the base to topsoil at the top.

\subsection{Granulometric Analysis}

The results of the granulometric analysis are summarized on Table 1 and presented as cumulative plots in Figure 6 and Figure 7. Graphic means calculated from first quartiles ( 25 percentile) and third quartiles (75 percentile) of the cumulative curves gave values ranging between $0.023-0.5 \mathrm{~mm}$ for Section 1 and $0.026-0.5 \mathrm{~mm}$ for Section 2. The graphic standard deviation values range between $0.8-2.4$ for Section 1 and $0.7-1.5 \mathrm{~mm}$ for Section 2 (Table 1). 

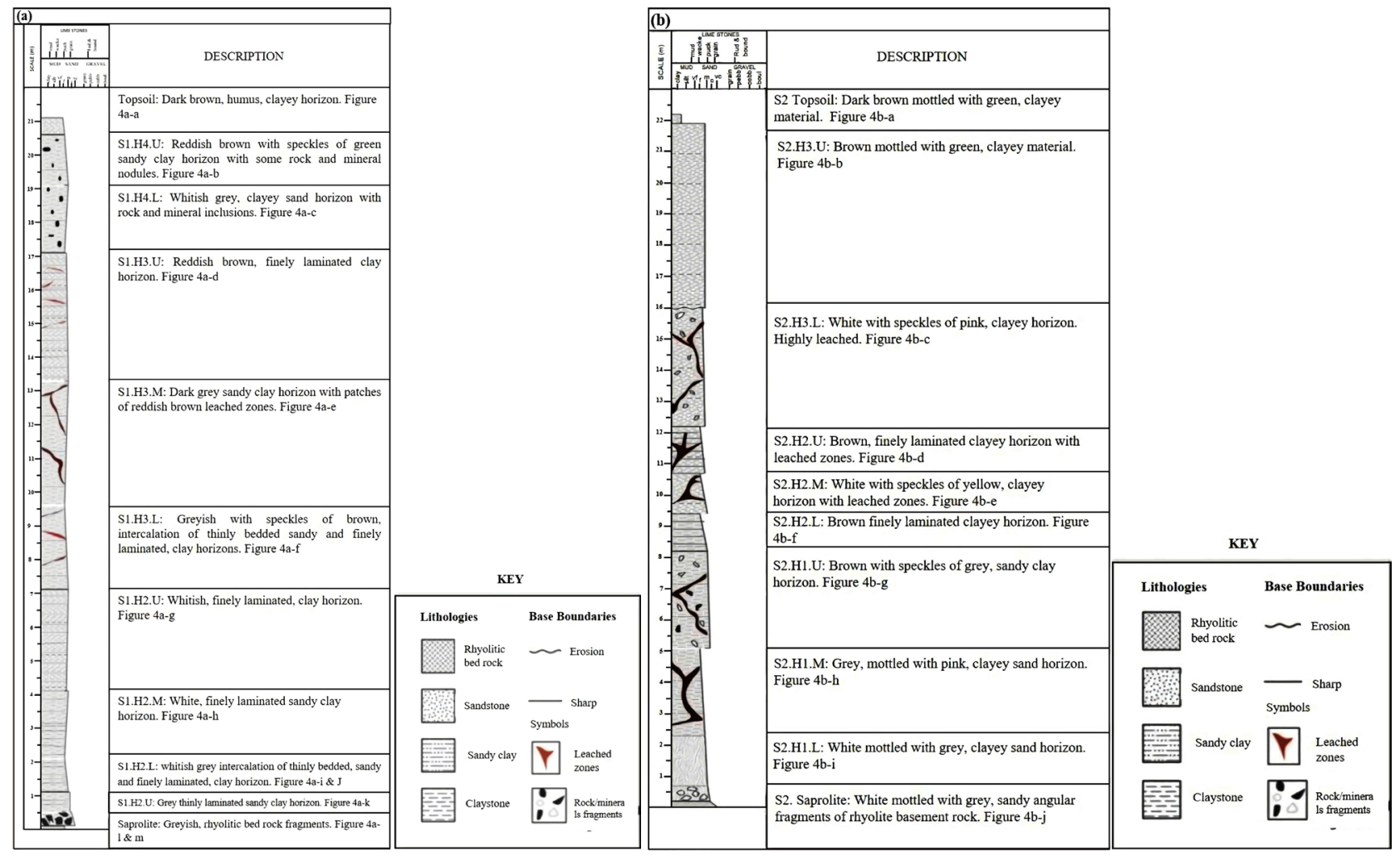

Figure 3. Log of weathered profiles from bottom to top showing vertical variations in colour, texture, structure, thickness and grain sizes of sampled horizons. $\mathrm{a}=$ Section $1 ; \mathrm{b}=$ Section $2 ; \mathrm{H}=$ horizon; $\mathrm{L}=$ Lower; $\mathrm{M}=$ Middle; $\mathrm{U}=$ Upper.
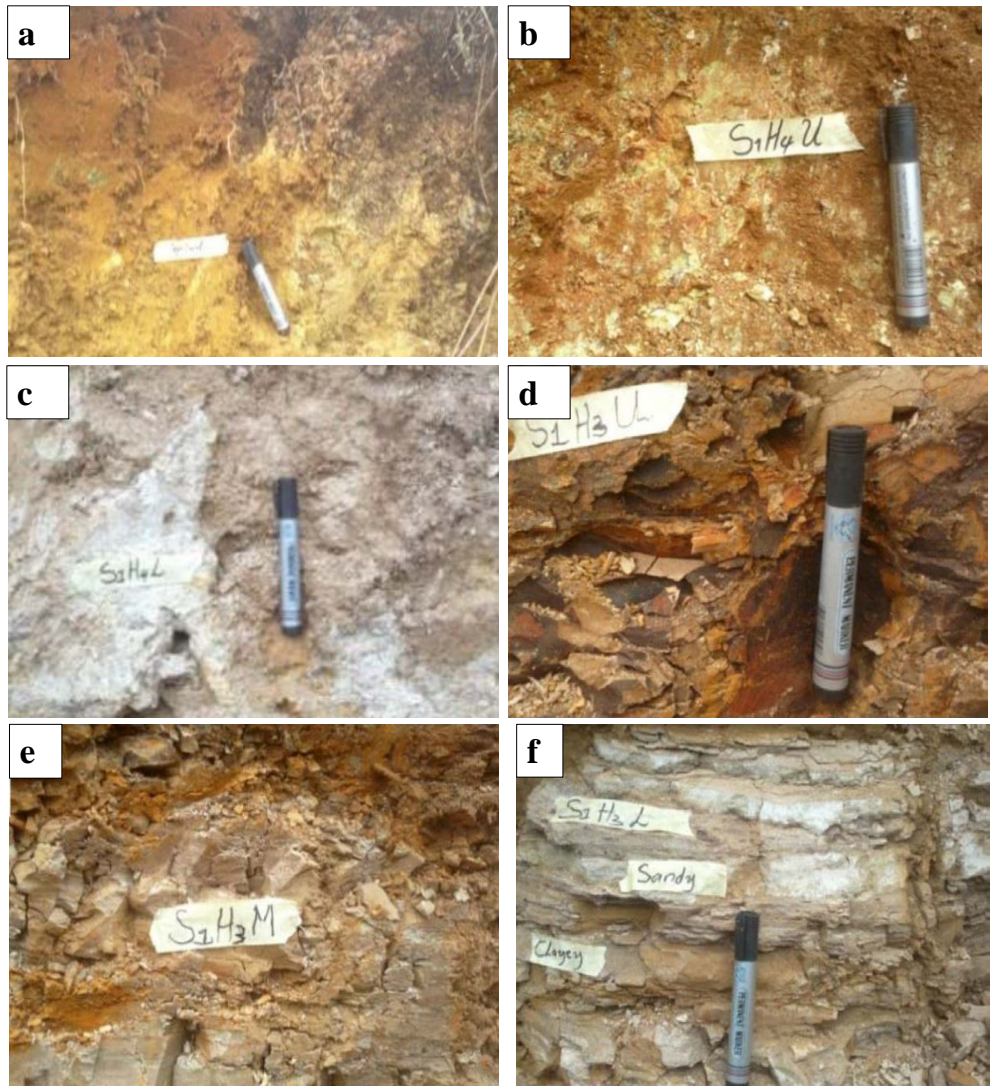

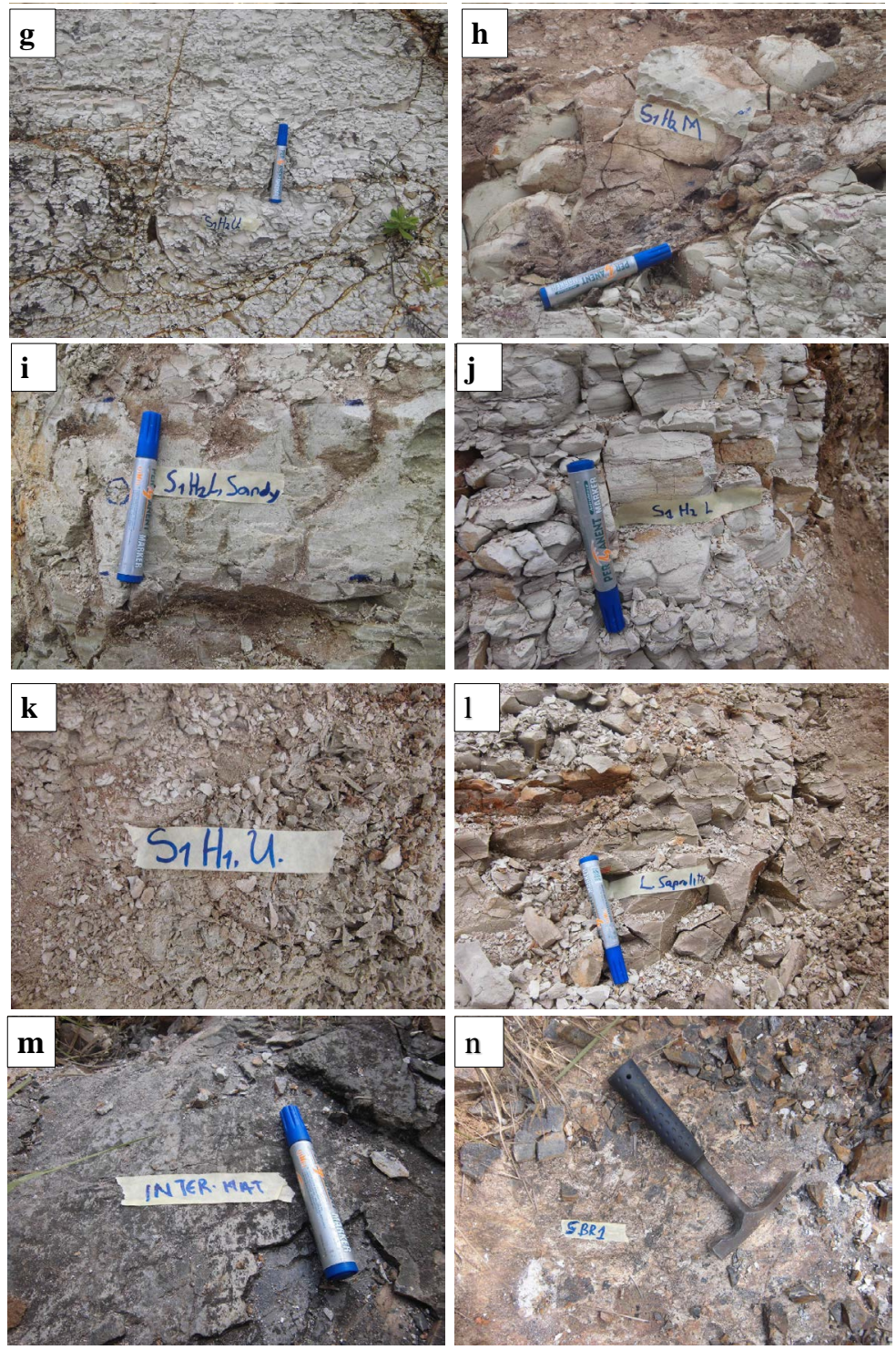

Figure 4. Field photographs of each sampled horizon of the weathered profile (Section 1) of the Sabga area (a) Topsoil horizon; dark brown, fine humus, plants roots present. (b) Upper zone of horizon 4 (S1.H4.U); reddish brown with mottles of green, fine sandy clay with incorporated dark and white angular-sub rounded minerals and rock nodules. (c) Lower zone of horizon 4 (S1.H4.L); whitish with speckles brown, fine clayey sand. (d) Upper zone of horizon 3 (S1.H3.U); brown, fine clayey horizon with rusty leached zones. (e) Middle zone of horizon 3 (S1.H3.M); greyish with speckles of brown, fine clayey horizon with rusty brown leached zones. (f) Lower zone of Horizon 3 (S1.H3.L); whitish, with grey mottles, intercalation of thinly bedded clay and sand. (g) Upper zone of horizon 2 (S1.H2.U); greyish white, clayey horizon with irregular cooling cracks. (h) Middle zone of horizon 2; greyish with speckles of brown, reddish brown leached zones present. (i) Thick white sand bed within lower zone of horizon 2, sub rounded mineral nodules present. (j) Lower zone of horizon 2 (S1.H2.L); whitish, finely laminated clayey sand horizon, shows very thin interaction of clay and sand sub rounded mineral nodules are present. (k) Upper zone of horizon 1 (S1.H1.U); grey, fine clayey horizon. (l) Saprolite; weathered, greyish, angular rhyolitic rock fragments showing some flow bands. (m) Thin dark weathered igneous material with cooling cracks, (n) Bedrock; white weathered rhyolitic material. 

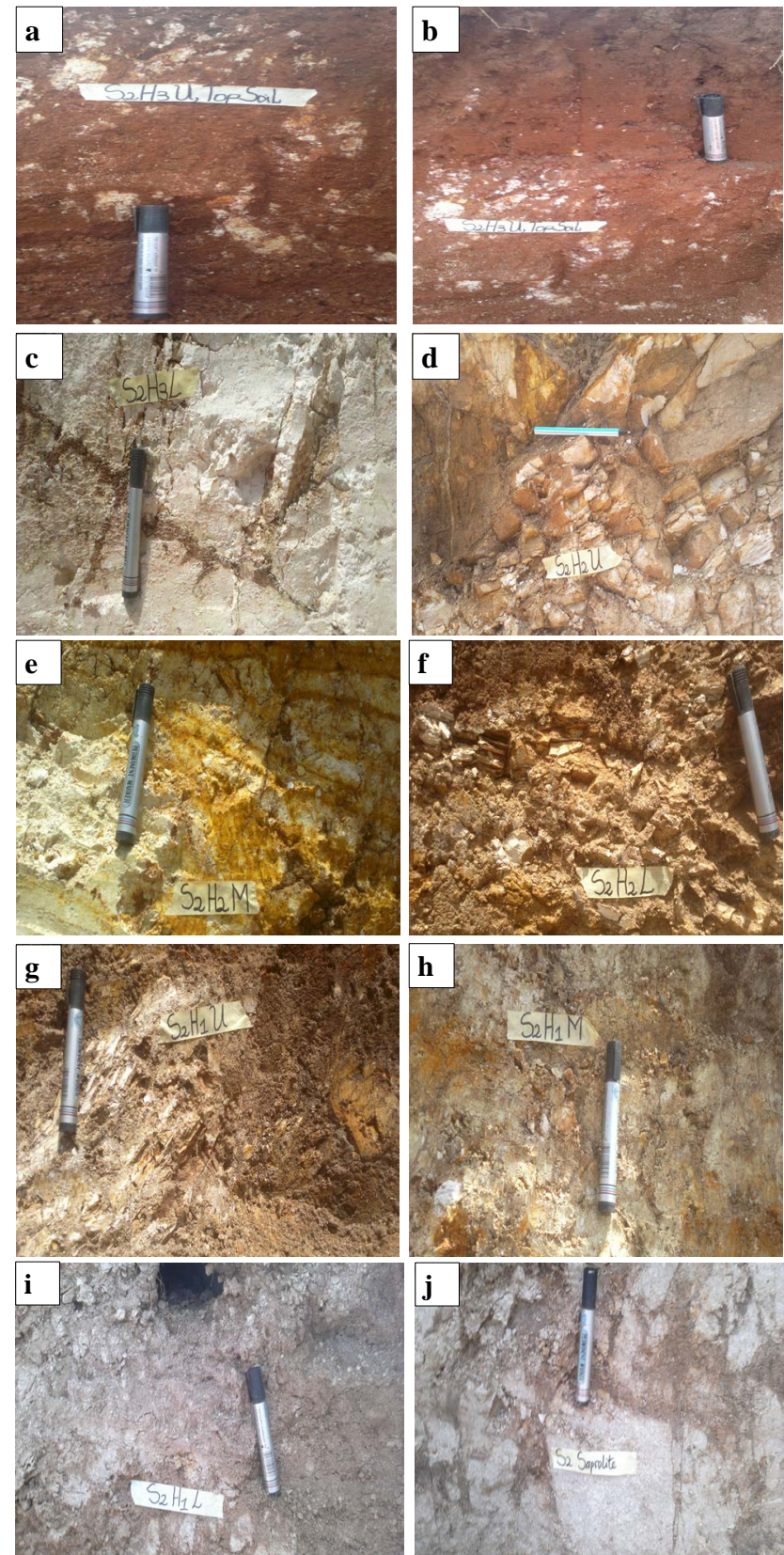

Figure 5. Field photographs of each sampled horizon of the weathered profile (Section 2) of the Sabga area (a) Topsoil; dark brown humus with speckles of white clayey materials at the lower portion of the zone. (b) Upper zone of horizon 3 (S2.H3.U); dark brown mottled with white clayey zone, angular-sub rounded mineral nodules are incorporated within the clayey materials. (c) Lower zone of horizon 3 (S2.H3.L); white mottled with pink, fine clays with brown leached zones and quartz mineral nodules. (d) Upper zone of horizon 2 (S2.H2.U); brown, finely laminated clayey zone, with patches of reddish brown leached zones. (e) Middle zone of horizon 2 (S2.H2.M); whitish with speckles of yellow, fine clayey zone, some leached zones present. (f) Lower zone of horizon 2 (S2.H2.L); brown, finely laminated clayey sand zone. (g) Upper zone of horizon 1 (S2.H1.U); brown, finely laminated sandy clays with angular quartz mineral nodules. (h) Middle zone of horizon 1 (S2.H1.M); brown with speckles of grey, clayey sand zone, with reddish brown leached zones. (i) Lower zone of horizon 1 (S2.H1.1); white with speckles of grey, medium sandy zone. (j) Saprolite; white with grey mottles and brown speckles, coarse sandy zone. 

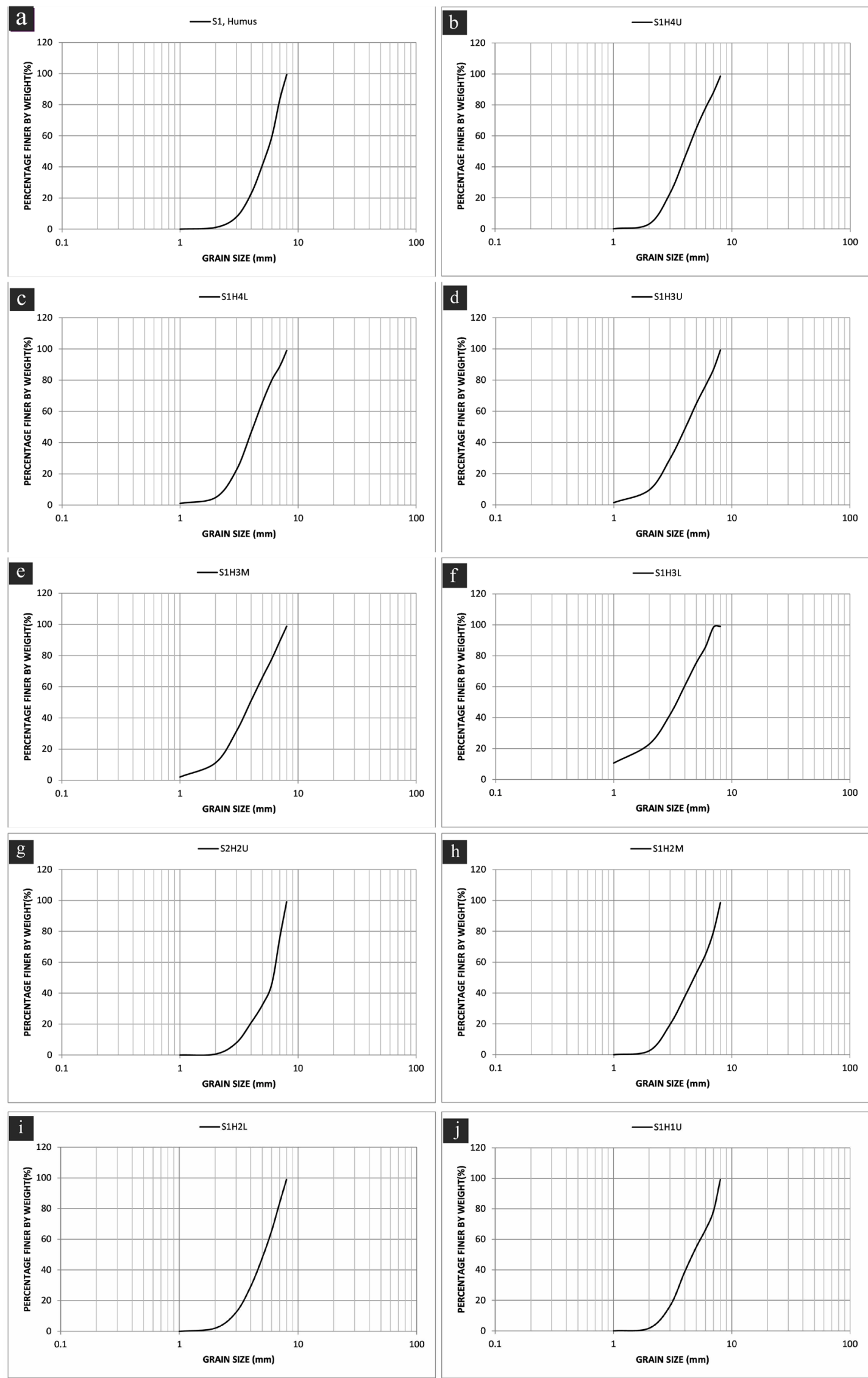


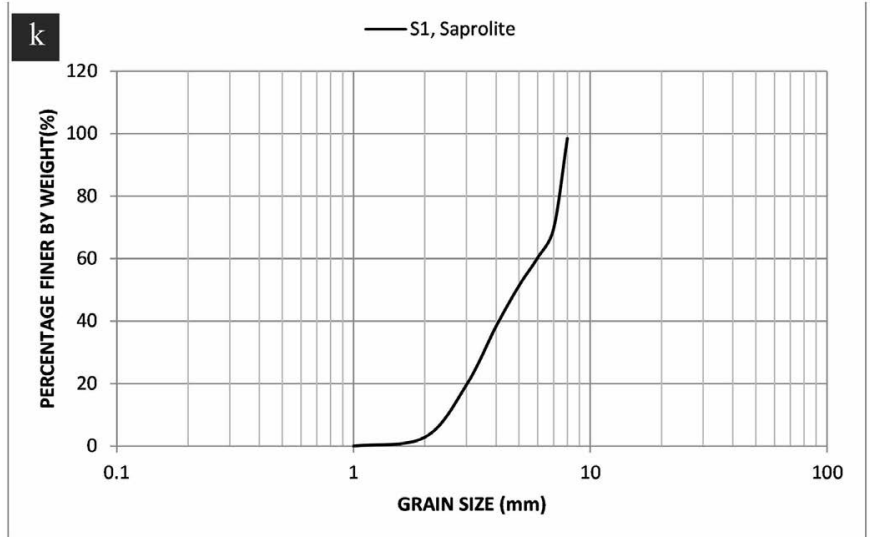

Figure 6. Representative cumulative curves for representative samples of each horizon of Section 1. (a) S1 topsoil; (b) S1H4U; (c) S1H4L; (d) S1H3U; (e) S1H3M; (f) S1H3L; (g) S1H2U; (h) S1H2M; (i) S1H2M; (j) S1H2L; (k) S1H1U; (L) S1 Saprolite.
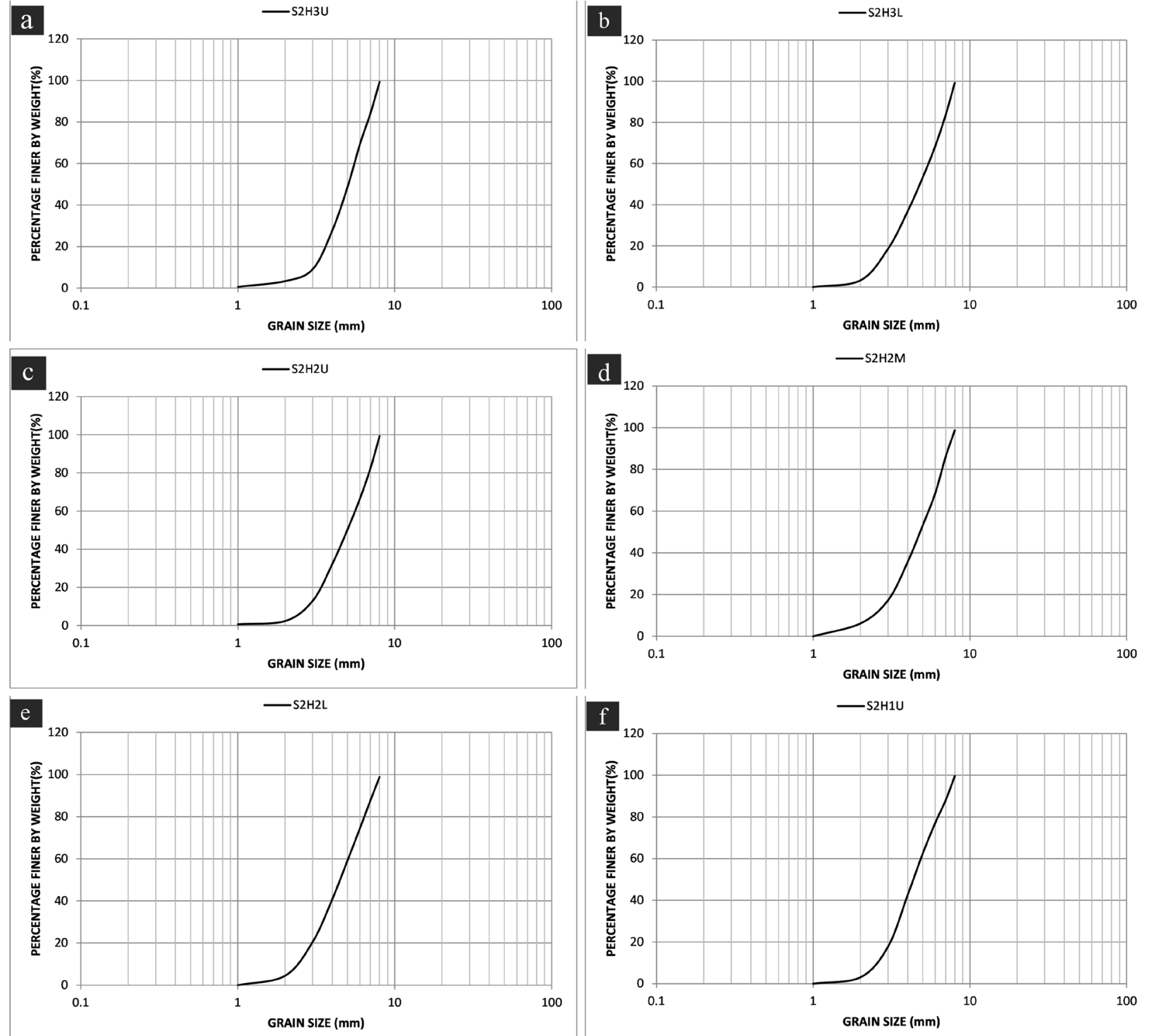

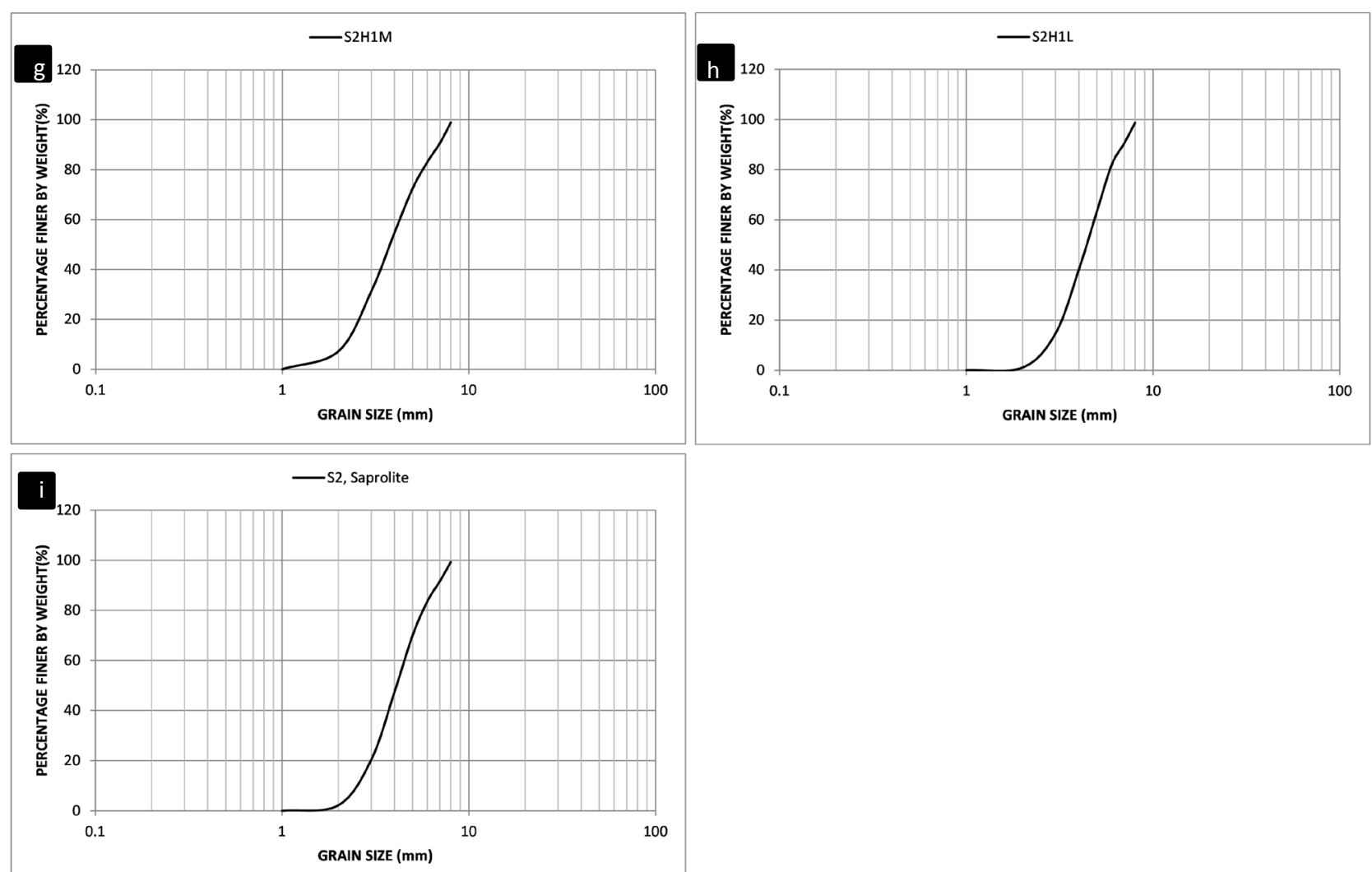

Figure 7. Representative cumulative curves for representative samples of each horizon in Section 2; (a) S2, Topsoil; (b) S2H3L; (c) S2H2U; (d) S2H2M; (e) S2H2L; (f) S2H1U; (g) S2H1M; (h) S2H1L; (i) S2, Saprolite.

Table 1. Graphic mean and inclusive standard deviation for Sections 1 and 2.

\begin{tabular}{ccc}
\hline Sample & GRAPHIC MEAN $(\mathrm{mm})$ & $\begin{array}{c}\text { GRAPHIC STANDARD } \\
\text { DEVIATION }(\mathrm{mm})\end{array}$ \\
S1H & 3.42 & 1.8 \\
TOPSOIL & 2.45 & 1.83 \\
S1H4U & 2.73 & 1.75 \\
S1H4L & 2.43 & 2.12 \\
S1H3U & 2.2 & 2 \\
S1H3M & 1.6 & 1.93 \\
S1H3L & 3.7 & 1.9 \\
S1H2U & 2.65 & 1.95 \\
S1H2M & 3.06 & 1.85 \\
S1H2L & 3.03 & 1.98 \\
S1H1U & 3.03 & 2.08 \\
SAPROLITE & & 1.88 \\
S2H & 3.2 & 2.03 \\
TOPSOIL & 2.93 & \\
S2H3L & &
\end{tabular}




\begin{tabular}{rcc} 
Continued & & \\
\hline S2H2U & 3.26 & 1.88 \\
S2H2M & 3.03 & 1.98 \\
S2H2L & 2.46 & 2.13 \\
S2H1U & 2.7 & 1.93 \\
S2H1M & 2.03 & 1.83 \\
S2H1L & 2.66 & 1.7 \\
SAPROLITE & 2.16 & 1.93
\end{tabular}

\subsection{Mineralogical Characteristics}

SEM displays spatial variations in mineralogy and morphology of the mineral crystals. The clay minerals in studied samples are mainly smectite occurring in ball-shape tubes and kaolinite flakes arranged in booklet forms (Figure 8). Quartz and feldspar occur as accessory minerals.

X-ray diffraction patterns (Figure 9) confirmed kaolinite peaks at $2 \theta$ angles of $12.3^{\circ}, 20.6^{\circ}$ and $36.8^{\circ}$ with d-spacing values of $7.15 \AA, 7.14 \AA$ and $3.15 \AA$, respectively. The very high kaolinite peak occurs at $2 \theta$ angle of $36.8^{\circ}$ with a d-spacing value of $3.15 \AA$. The peaks for smectite are at $2 \theta$ angle of $22.6^{\circ}$ and $33.5^{\circ}$ with d-spacing values of $4.47 \AA$ and $3.34 \AA$ respectively. The kaolinite and smectite peaks are contaminated with quartz at $2 \theta$ angles of $25.4^{\circ}$ and $36.5^{\circ}$ with $\mathrm{d}$-spacing values of $4.17 \AA$ and $3.32 \AA$ respectively.

\section{Interpretation and Discussion}

After the text edit has been completed, the paper is ready for the template. Duplicate the template file by using the Save As command, and use the naming convention prescribed by your journal for the name of your paper. In this newly created file, highlight all of the contents and import your prepared text file. You are now ready to style your paper.

\subsection{Texture and Colour Variations within the Weathered Profiles from the Saprolitic Zone to Topsoil}

Logs (Figure 3(a) and Figure 3(b)) of both sections show vertical variations in color, textures and structures from the saprolitic zone progressively towards the topsoil (Figure 4 and Figure 5). The saprolitic zones and lower horizons appear whitish speckled with grey, showing some fine laminations typically observed in rhyolitic lavas. This indicates that the initial texture of the parent rock is conserved even though some horizons displayed interconnected rusty fractures and cooling cracks. The fine lamination confirms that the bedrock material is rhyolitic in composition. The higher horizons show variable colors of grey, yellow and reddish brown, with some horizons stained with rusty brown leached zone. Colour variations are indicative of an oxygen-rich environment (oxic), favouring the alteration of feldspar and the presence of iron-rich minerals such as goethite. 

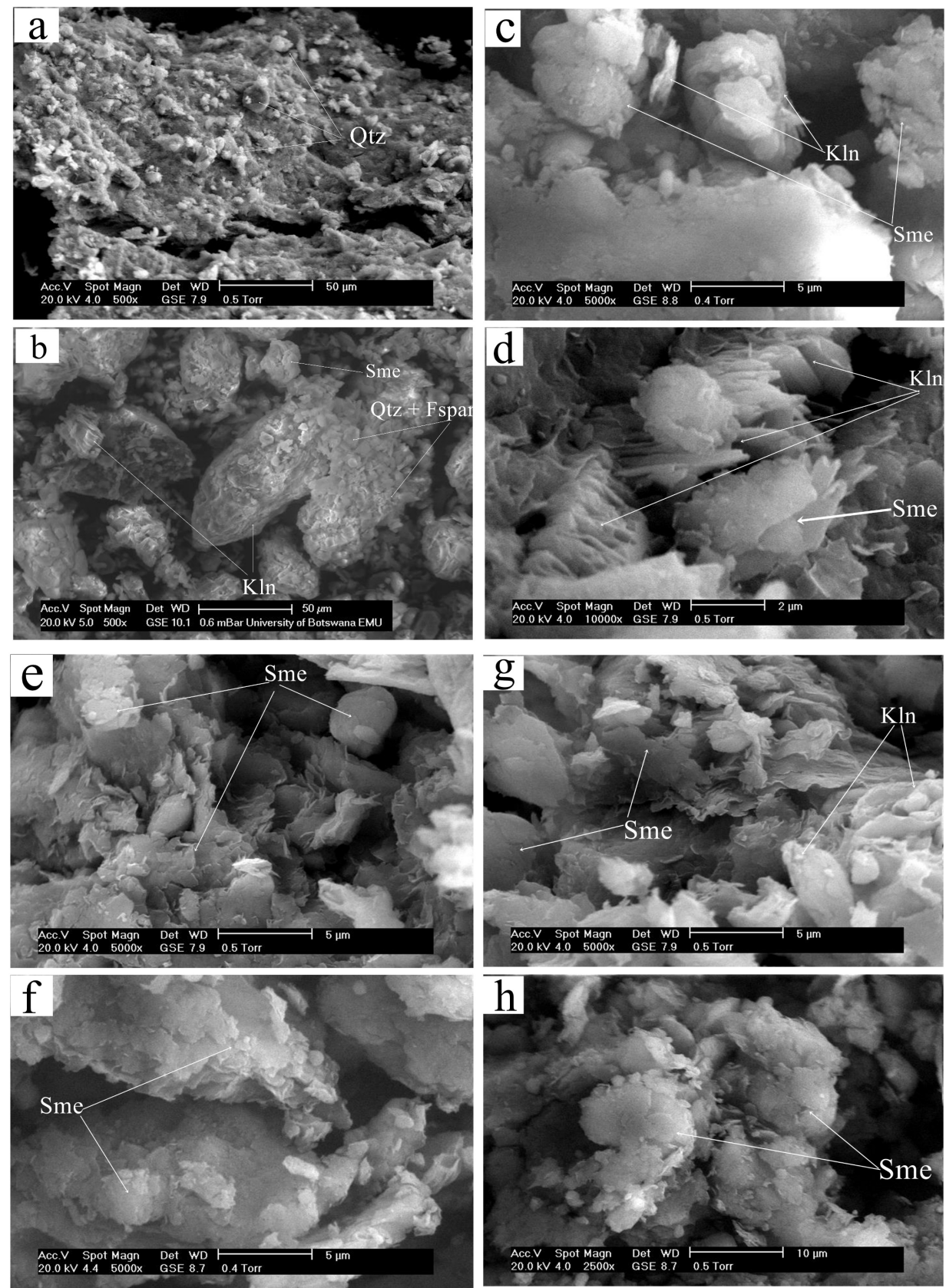

Figure 8. Representative SEM micrographs of clays from Sabga (Section 1) (a) SEM micrograph of S1 Topsoil; non-diagnostic clayey material rich in microcrystic laths of quartz. (b) SEM micrograph of S1H4 composite; lath-like "balls" of interlocking dioctahedral Smectite with few flaky "booklets" of pseudo hexagonal kaolinite, with loose microcrystic laths of quartz and feldspars in the matrix. (c) SEM micrograph of S1H3 composite; wavy "ball" of smectite with few flaky kaolinite. (d) SEM micrographs of S1H2U; Flaky "booklets" of well crystallized kaolinite displaying stepped appearance with few poorly crystalized lath-like "ball" of hexagonal smectite. (e) SEM micrograph of S1H2M; desiccated wavy "ball" shaped flakes of hexagonal smectite. (f) SEM micrograph of S1H2L; Flaky "balls" of well crystallized polygonal smectite. (g) SEM micrograph of S1H1U; Wavy "balls" of interpenetrating and interlocking hexagonal smectite with few flaky "booklets" of poorly crystallized pseudo-hexagonal kaolinite. (h) SEM micrograph for S1 Saprolite, lath-like "balls" of interpenetrating and interlocking dioctahedral aggregate of smectite clay. 


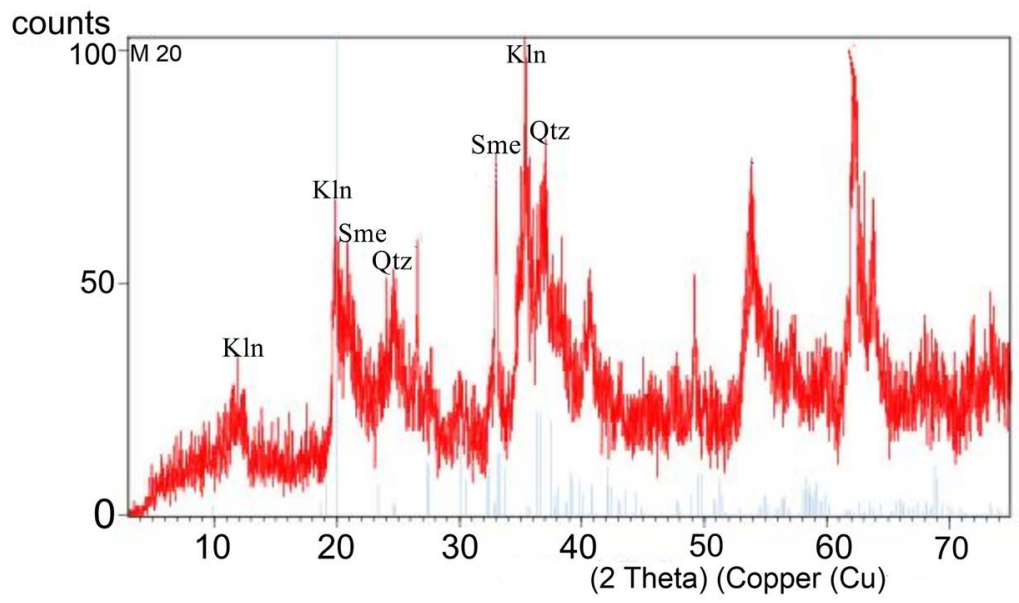

Figure 9. Sample of X-ray pattern for S1H1U, showing high peaks of kaolinites together with smectite peaks both contaminated by quartz.

[16] [37]. The rusty leached zones are implications of the chemical weathering process and represent incipient oxidation which is usually common in tropical regions. Quartz mineral nodules found in some horizons are indicative of the minerals high resistance to weathering and also confirms the high silica content of the bed rock.

Weathered profiles of both Sections 1 and 2 show some similarities in textural and color variations except for the fact that the Saprolitic zone of Section 2 is almost entirely sandy as appose to the weathered rhyolitic saprolite of Section 1. This does not imply a change in bedrock material but can rather be explained as a function of the location of the two sections with respect to altitude. With increasing altitude the rate of weathering increases. The weathered profile in Section 2 is situated at a higher altitude (1631 - 1659 m.a.s.l) as compared to that of Section 1 (1626 - 1649 m.a.s.l) as such the bed rock should have weathered faster leaving behind fine clayey and sandy materials. Grain size analysis results (Figure 6, Figure 7, Table 1) show that graphic mean values for samples in Sections 1 and 2 range between $2.02-3.36 \phi$ and $2.2-3.7 \phi$ respectively, with an average inclusive graphic standard deviation of $1.92 \phi$ and $1.97 \phi$ respectively. These results indicate that the particle sizes are made up of poorly sorted sand (medium-very fine), silt (medium-fine) and clay $(<63 \mu \mathrm{m})$ with insignificant quantity of nodular fractions. This grain size distribution falls within that described by [15]. The grain size distribution can be classed as clayey sand and clayey silt. Clay sized particles were computed from the percentage of the $<63 \mu \mathrm{m}$ mesh fractions retained in the pan. This particle size distribution of sandy clays and silty clays has been described by [12] where the sand particles were separated by wet sieving and the clay fraction separated through successive sedimentation methods. The proportion of the fine particles especially the clay sized particles determine the plasticity of the weathered product. Plasticity and particle size are amongst the main geotechnical characteristics to determine a convenient choice of construction materials. The particle size distribution of this study conforms 
with that of [11] carried out in the Oku highlands and to that [15] in the Sabga area. Thus the Sabga clays can be used for civil engineering purposes, oil refining, heavy metal retention, foundry bonding, ceramics and waste disposal.

\subsection{Mineralogical Characterization of the Weathered Profiles}

Results from SEM micrographs (Figures 8(a)-(g)) revealed that the dominant clay minerals in the weathered profiles are the "ball" shaped interlocking hexagonal smectite and the flaky "booklets" pseudo-hexagonal authigenic kaolinite associated with microcrystic flakes of quartz and feldspars. The XRD pattern of S1H1U (Figure 9) generally shows very broad basal reflections for kaolinite with the lowest and highest peaks at $2 \theta$ angles of $12.3^{\circ}$ (7.15 $\AA$ ) and $36.8^{\circ}(3.15 \AA)$ respectively. Smectites have basal reflections at $2 \theta$ angles of $22.6^{\circ}(4.47 \AA)$ and $33.5^{\circ}$ (3.34 $\AA$ ) the peaks of kaolinite and smectite are contaminated with quartz at $2 \theta$ angles of $25.4^{\circ}\left(4.17 \AA\right.$ ) and $36.5^{\circ}$ (3.32 $\AA$ ). The basal reflection in the above ranges at the $2 \theta$ angles for the above mentioned minerals are typical for these minerals. Combining SEM and XRD analysis result both gave smectite and kaolinite as the dominant minerals in association with some quartz and feldspars. According to [11], montmorillonite is the smectite type in the Sabga area after treating the clay deposit with glycerol, Li-saturation and heating (Greene-Kelly test).

Similar to the results from textural variations there is progressive heterogeneity from the saprolite towards the topsoil in terms of mineralogy. The SEM micrographs for the saprolite and lower horizons (Figure 8(h), Figure 8(g), Figure 8(f) and Figure 8(e)) show that the mineral present is smectite (Figure 8). Midway within the profile (S1H2U and S1H3 composite: Figure 8(c) and Figure $8(d))$ the SEM shows that smectite and kaolinite co-exist within the profile. The SEM data for the upper horizons (S1H4 composite and the topsoil: Figure 8(a) and Figure 8(b)) shows that the minerals present are kaolinite and quartz + feldspar respectively. This is in agreement with the work of [5] which stipulates that kaolinite is usually the dominant clay mineral formed on the upper and middle sections of slopes under a good drainage system on suitable rocks while smectite and illite will replace kaolinite as the dominant clay mineral formed down slope under poor drainage systems.

[11] in unraveling the paragenesis of the clay stipulated that the Sabga clays are located in both the lower and upper slopes of the landscape with altitudes ranging between 1500 - $1700 \mathrm{~m}$ above sea level (a. s. l). The mineral paragenesis according to Mache et al. [11] shows montmorillonite \pm cristobalite \pm feldspar \pm kaolinite \pm ilmenite \pm heulandite. This mineral paragenesis is similar to that of [15]. This paragenesis suggests that clay formation is still in progress with continuous alteration of feldspars. The clay minerals according to both authors are geochemically derived from the weathering of trachyte parent rock. Compared to the minerals identified in the present study for weathered products developed from rhyolites, the mineral paragenesis is similar but for the oxides of iron and heulandite which have not been identified may be due to their very low content. 
The presence of smectites and kaolinite as well as fine particle sizes gives the Sabga clays the potential to be used in pharmaceutical industries as reported by [15], after treatment to reduce toxic chemicals and crystalline quartz. A combination of kaolinite and smectite, and fine particle sizes could contribute to the alleviation of gastrointestinal discomfort related to diarrhea and the elimination of toxins in geophagic individuals.

Similar to previous studies, no hydrothermal minerals were identified. [9] suggested that the absence of hydrothermal alteration minerals such as pyrite, hydroxyl apatite or any other associated ore minerals indicated the residual origin of clay deposits. Therefore the Sabga clay deposits are residual in origin with the clay minerals formed from the meteoric weathering of feldspars since no hydrothermal alteration minerals have also been identified in this study. The kaolinites from Sabga are similar with the quartz-rich kaolinites from the Mayouom deposit in West Cameroon [38], kaolinites from the Douala Sub-basin [16]. The book-like nature of kaolinite flakes suggest their transportation and deposition in piles [39]. According to [11] the main smectite clays from Sabga area are montmorillonite. These smectites are different from the quartz-rich smectites developed in confined environments within Sahelian climate conditions as in northern Cameroon.

\section{Conclusions}

Textural and mineralogical characterization of rhyolitic weathered profiles carried out in the Sabga area, NW Cameroon has revealed that particle size distribution for the samples from the saprolite zone towards the topsoil range from poorly sorted sand, silt to clay at different percentages. The dominant clay minerals found in the weathered products are smectites and kaolinite with variable amounts of quartz and feldspar. Smectite laths occur in the lower horizon, flakes of kaolinite and laths of smectite in the middle horizon with the occurrence of kaolinite flakes, quartz microlites and feldspar in the upper horizon. No hematite, heulandite and hydrothermal alteration minerals have been identified. The presence of smectites and kaolinite as well as fine particle sizes give the Sabga clays the potential to be used in pharmaceutical industries after treatment.

The weathered profiles show clear vertical heterogeneity in color, texture and structure from the saprolitic zone (white mottled with grey, finely laminated clayey sand) - the middle horizons (brown, clayey silt with cooling cracks) - upper horizons (reddish brown, clayey silt with rusty brown leached zones) to the topsoil (dark brown, clayey).

\section{Acknowledgements}

The authors are grateful to the staff at EMU unit of the Geology Laboratory, University of Botswana, (Gaborone) for performing analysis on the samples.

\section{Conflicts of Interest}

The authors declare no conflicts of interest regarding the publication of this paper. 


\section{References}

[1] Velde, B. (1992) Introduction to Clay Minerals. Springer, Dordrecht, 198. https://doi.org/10.1007/978-94-011-2368-6

[2] Deepthy, R. and Balahrishnan, J. (2005) Climatic Control on Clay Mineral Formation: Evidence from Weathering Profiles Developed on Either Side of the Western Ghats. Journal of Earth Systems, 114, 545-556. https://doi.org/10.1007/BF02702030

[3] Soubrand-Colin, M., Bril, H., Néel, C., Coutine-Nomade, A. and Martin, F. (2005) Weathering of Basaltic Rocks from the French Massif Central: Origin and Fate of $\mathrm{Ni}, \mathrm{Cr}, \mathrm{Zn}$, and $\mathrm{Cu}$. The Canadian Mineralogist, 43, 1077-1091. https://doi.org/10.2113/gscanmin.43.3.1077

[4] Siefferman, G. and Millot, G. (1969) Equatorial and Tropical Weathering of Recent Basalts from Cameroon: Allophanes, Halloysite, Metahalloysite, Kaolinite and Gibbsite. International Clay Conference, Tokyo, 5-10 September 1969, Vol. 1, 417-430.

[5] Irfan, T.Y. (1996) Mineralogy, Fabric Properties and Classification of Weathered Granites in Hong Kong. Quarterly Journal of Engineering Geology and Hydrogeology, 29, 5-35. https://doi.org/10.1144/GSL.QJEGH.1996.029.P1.02

[6] Eggleton, R.A., Fouddolus, C. and Varkevisser, D. (1987) Weathering of Basalt: Changes in Rock Chemistry and Mineralogy. Clays and Clay Minerals, 35, 161-169. https://doi.org/10.1346/CCMN.1987.0350301

[7] Im, C.B., Koh, S.M., Chang, H.W. and Takagi, T. (2002) The Geochemical Behavior of Altered Igneous Rocks in the Tertiary Gampo Basin, Kyongsang Province, South Korea. Geochemical Journal, 36, 391-407. https://doi.org/10.2343/geochemj.36.391

[8] Njoya, A., Ekodeck, G.E., Nkoumbou, C., Njopwouo, D. and Tchoua, M.F. (2001) Clay Materials in Cameroon: Deposits and Exploitation. In: Nkoumbou, C. and Njopwouo, D., Eds., Actes of the first Conference on the Valorization of Clay Materials in Cameroon, Yaoundé, Cameroun, 13-30.

[9] Njoya, A., Nkoumbou, C., Grosbois, C., Njopwouo, D., Njoya, D., Courtin-Nomade, A. and Martin, F. (2006) Genesis of Mayouom Kaolin Deposit (Western Cameroon). Applied Clay Science, 32, 125-140. https://doi.org/10.1016/j.clay.2005.11.005

[10] Ossah, N.H. (1975) Alteration of Volcanic Rocks in Mount Bamenda, Cameroon. Geology, Mineralogy and Geochemistry. Doctorate Dissertation, Third Cycle of Doctorate Degree, University of Paris VI, France.

[11] Mache, J.R., Signing, P., Njoya, A., Kunyukubundo, F., Mbey, J.A., Njopwouo, D. and Fagel, N. (2013) Smectite Clay from the Sabga deposit (Cameroon): Mineralogical and Physicochemical Properties. Clay Minerals, 48, 499-512. https://doi.org/10.1180/claymin.2013.048.3.07

[12] Logmo, E.O., Ngon, G.F.N., Samba. W., Mboy, M.B. and Etame, J. (2013) Geotechnical, Mineralogical and Chemical Characterization of the Missole II Clayey Materials of Douala Sub-Basins (Cameroon) for Construction Materials. Open Journal of Civil Engineering, 3, 46-53. https://doi.org/10.4236/ojce.2013.32A006

[13] Nzeuko, A.N., Kamgang, V.K., Medjo, R.E., Melo, U.C., Njoya, A., et al. (2013) Industrial Potentiality of Alluvial Clays Deposits from Cameroon: Influence of Lateritic Clayey Admixtures for Fire Bricks Production. Journal of Minerals and Materials Characterization and Engineering, 1, 236-244.

https://doi.org/10.4236/jmmce.2013.15037

[14] Onana, V.L., Ntouala, R.F.D., Effoudou, E.N., Nguembou, C.Y., Nguessi, A. and Kabayene, V.K. (2016) Mineralogical, Geochemical and Geomechanical Characterization of Lateritic and Alluvial Clayey Mixture Products from Monatele-Ebebda, 
as Building Materials. Journal of the Cameroon Academy of Sciences, 13, 23-38.

[15] Kalguem, E.D.K., Wouatong, A.S.L., Njopwouo, D., Kemteu, C.S. and Ekosse, G.I. (2019) Geophagic Clayey Materials of Sabga Locality (North West Cameroon): Genesis and Medical Interest. Earth Sciences, 8, 45-59.

https://doi.org/10.11648/j.earth.20190801.14

[16] Bukalo, N., Ekisse, G.-I., Odiyo, J. and Ogola, J. (2020) Geochemistry and Possible Industrial Applications of Cretaceous-Tertiary Kaolins of the Douala Sub-Basin, Cameroon. Periodico di Mineralogia, 89, 225-242.

[17] Duzgoren-Aydin, N.S. and Aydin, A. (2003) Chemical Heterogeneities of Weathered Igneous Profiles: Implications for Chemical Indices. Environmental Engineering, Geosciences, 9, 363-376. https://doi.org/10.2113/9.4.363

[18] Che, V.B., Fontijn, K., Ernest, G.G.J., Kervyn, M., Elburg, M., Ranst, E.V. and Suh, C.E. (2012) Evaluating the Degree of Weathering in Landslide-Prone Soils in the Humid Tropics: The Case of Limbe, SW Cameroon. Geodema, 170, 378-389. https://doi.org/10.1016/j.geoderma.2011.10.013

[19] Kamgang, P., Njonfang, E., Nono, A., Gountie Dedzo, M. and Tchoua, M.F. (2010) Petrogenesis of a Silicic Magma System: Geochemical Evidence from Bamenda Mountains, NW Cameroon, Cameroon Volcanic Line. Journal of African Earth Sciences, 58, 285-304. https://doi.org/10.1016/j.jafrearsci.2010.03.008

[20] Fitton, J.G. and Dunlop, H.M. (1985) The Cameroon Line, West-Africa, and Its Bearing on the Origin of Oceanic and Continental Alkali Basalt. Earth and Planet Science Letters, 72, 23-38. https://doi.org/10.1016/0012-821X(85)90114-1

[21] Fitton, J.J. (1987) The Cameroon Line, West Africa: A Comparison between Oceanic and Continental Alkaline Volcanism. Geological Society, London, Special Publication, 30, 273-291. https://doi.org/10.1144/GSL.SP.1987.030.01.13

[22] Déruelle, B., Ngounouno, I. and Demaiffe, D. (2007) The "Cameroon Hot Line": A Unique Example of Active Alkaline Intraplate Structure in Both Oceanic and Continental Lithosphere. Comptes Rendus Geoscience, 339, 589-600. https://doi.org/10.1016/j.crte.2007.07.007

[23] Moundi, A., Wandji, P., Bardintzeff, J.-M., Ménard, J.-J., Okomo Atouba, L.C., Mouncherou, O.F., Reusser, É., Bellon, H. and Tchoua, F.M. (2007) Les basaltes éocènes à affinité transitionnelle du plateau Bamoun, témoins d'un réservoir mantellique enrichi sous la ligne volcanique du Cameroun. Comptes Rendus Geoscience, 339, 396-406. https://doi.org/10.1016/j.crte.2007.04.001

[24] Njome, M.S. and De Wit, M.J. (2014) The Cameroon Line: Analysis of an Intraplate Magmatic Province Transecting Both Oceanic and Continental Lithospheres: Constraints, Controversies and Models. Earth Science Review, 139, 168-194.

https://doi.org/10.1016/j.earscirev.2014.09.003

[25] Bate Tibang, E.E., Suh, C.E., Cottle, J., Ateh, K.I., Tiabou, A.F., Nche, L.A., Che, V.B. and Vishiti, A. (2017) Petrology and Geochronology of Felsic Volcanics in the Sabga area (Bamenda Highlands): Implications for Age Variation along the Cameroon Volcanic Line. Journal of Geosciences, 62, 231-249.

https://doi.org/10.3190/jgeosci.247

[26] Burke, K. and Whiteman, A.J. (1973) Uplift, Rifting and Break-up of Africa. In: Tarling, D.H. and Runcorn, S.K., Eds., Implications of Continental Drift to the Earth Sciences, 2nd Edition, Acadamic Press, London, 735-755.

[27] Toteu, S.F., Van Schmus, W.R., Penaye, J. and Nyobe, J.B. (1994) U-Pb and Sm-Nd Evidence for Eburnian and Pan-African High Grade Metamorphism in Cratonic Rocks of Southern Cameroon. Precambrian Research, 67, 321-347. 
https://doi.org/10.1016/0301-9268(94)90014-0

[28] Van Schmus, W., Oliverra, E.P., Da Silva Filho, A.F. and Toteu, S.F. (2008) Proterozoic Links between the Borborema Province, NE Brazil, and the Central African Fold Belt. In: Pankhurst, R.T., Trouw, R.A.J., Brito Neves, B.B. and De Wit, M.J., Eds., West Gondwana: Pre-Cenozoic Correlations across the South Atlantic Region, Vol. 294, Geological Society of London, London, 69-99. https://doi.org/10.1144/SP294.5

[29] Marzoli, A., Renne, P.R., Piccirillo, E.M., Castorina, F., Bellieni, G., Melfi, A.J., et al. (1999) Silicic Magmas from the Continental Cameroon Volcanic Line (Oku, Bambouto and Ngaoundere): ${ }^{40} \mathrm{Ar} /{ }^{39} \mathrm{Ar}$ Dates, Petrology, Sr-Nd-O Isotopes and Their Petrogenetic Significance. Contributions to Mineralogy and Petrology, 135, 133-150. https://doi.org/10.1007/s004100050502

[30] Kamgang, P., Njonfang, E., Chazot, G. and Tchoua, F. (2007) Géochimie et géochronologie des laves felsiques des Monts Bamenda (Ligne Volcanique du Cameroun). Comptes Rendus Géoscience, 339, 659-666.

https://doi.org/10.1016/j.crte.2007.07.011

[31] Kamgang, P., Chazot, G., Njonfang, E. and Tchoua, F. (2008) Geochemistry and Geochronology of Mafic Rocks from Bamenda Mountains (Cameroon): Source Composition and Crustal Contamination along the Cameroon Volcanic Line. Comptes Rendus Geoscience, 340, 850-857. https://doi.org/10.1016/j.crte.2008.08.008

[32] Kamgang, K., Chazot, G., Njonfang, E., Ngongang, N.B. and Tchoua, F.M. (2013) Mantle Sources and Magma Evolution Beneath the Cameroon Volcanic Line: Geochemistry of Mafic Rocks from the Bamenda Mountains (N.W, Cameroon). Gondwana Research, 24, 727-741. https://doi.org/10.1016/j.gr.2012.11.009

[33] Gountié Dedzo, M., Nédélec, A., Njanko, T., Nono, A., Font, E. and Launeau, P. (2011) Magnetic Fabrics and Sources of Miocene Ignimbrites from West-Cameroon. Implications for Pyroclastic Flow Source and Sedimentation. Journal of Volcanology and Geothermal Research, 203, 113-132. https://doi.org/10.1016/j.jvolgeores.2011.04.012

[34] Reimer, L. (1998) Scanning Electron Microscopy: Physics of Image Formation and Microanalysis. Springer, Berlin, Heidelberg, 527.

[35] Egerton, R.F. (2005) An Introduction to Microscopy. In: Physical Principles of Electron Microscopy, Springer, Boston, 1-25. https://doi.org/10.1007/0-387-26016-1_1

[36] Shemang, E.M., Ekosse, G.E., Suh, C.E., Likkason, O.K. and Maigari, A.S. (2004) An Evaluation of Palaeocene Kaolin Deposits in North Eastern Nigeria. Neues Jahrbuch für Mineralogie-Abhandlungen, 180, 33-44. https://doi.org/10.1127/0077-7757/2004/0180-0033

[37] Fontes, M.P.F. and Carvalho Jr., I.A. (2005) Color Attributes and Mineralogical Characteristics, Evaluated by Radiometry of Highly Weathered Tropical Soils. Soil Science Society of America Journal, 69, 1162-1172. https://doi.org/10.2136/sssaj2003.0312

[38] Tassongwa, B., Eba, F., Njoya, D., Numbem, J., Jeudong, N., Nkoumbou, C. and Njopwouo, D. (2017) Physico-Chemistry and Geochemistry of Balengou Clay Deposit (West Cameroon) with Inference to an Argillic Hydrothermal Alteration. Compte Rendu Geoscience, 349, 212-222. https://doi.org/10.1016/j.crte.2017.06.002

[39] Keller, W.D. (1978) Classification of Kaolins Exemplified by Their Textures in Scan Electron Micrographs. Clays and Clay Minerals, 26, 1-20.

https://doi.org/10.1346/CCMN.1978.0260101 